\title{
Az irgalmas szeretet és a karitász jelentősége az egyház hármas - kormányzati, megszentelő és tanító - küldetésében ${ }^{1}$
}

\section{UJHÁZI LÓRÁND²}

A karitatív szeretet a három ág mellett - kormányzati, megszentelö és a tanitó - külön nincs nevesítve az egyházban, de jelentösége miatt az átsugárzik mind a kormányzó, mind a megszentelö, mind a tanító küldetésre. Söt a karitativ szeretet egyfajta összekötö kapocs is az emlitett három ág között. Lehetetlen az egyház kormányzati, megszentelö vagy tanitó küldetéséröl beszélni, anélkül, hogy az egyben ne lenne kapcsolatban a karitásszal. A karitász az egyház hármas tevékenységében való egyetemes megjelenése miatt el is mosódnak a határok: sokszor a szeretet tetteinek konkrét megnyilvánulása egyszerre tartozik a tanitó, a megszentelö vagy a kormányzati tevékenységhez. A karitász rendkivül sokszinü az egyház életében. Ebben a tanulmányban ennek fényében arra keresem a választ, hogy a karitativ szeretet alapitótól származó példája és utasítása hogyan érvényesül a hármas - kormányzás, megszentelés és tanitás - küldetés területén.

Kulcsszavak: Katolikus Egyház, karitász, kormányzás, tanítás, megszentelés

\section{The Significance of Charity in the Activities and Life of the Catholic Church from the Point of View of Canon Law}

Charity is not specified beside the three branches in the Church - governing, sanctifying and teaching -, but because of its importance it throws light on the governing, sanctifying and teaching missions. Moreover, charity works as a kind of link between the mentioned three branches. It is impossible to speak about the governing, sanctifying and teaching missions of the Church without having its connection with the caritas. Because of the universal appearance of the caritas in the threefold activity of the Church the boundaries are becoming more blurred: in many cases the specific manifestation of charity belongs to any activity of the governing, sanctifying and teaching mission at

1 A kutatás a Nemzeti Közszolgálati Egyetem „A fenntartható biztonság és társadalmi környezet” Tématerületi Kiválósági Program, a „Biztonság és honvédelem kutatócsoport” (Hadtudományi és Honvédtisztképző Kar) támogatásával készült.

2 PhD, tudományos főmunkatárs, NKE, HHK. Vallás és Biztonság Kutatóműhely vezetője, föszentszéki bíró Esztergom-Budapesti Érseki Bíróság. 
the same time. What is more, the caritas is multi-coloured in the life of the Church. In this study I am looking for the answer how the example and order of charity, originating from the founder, functions in the area of the threefold - governing, sanctifying and teaching - mission.

Keywords: Catholic Church, caritas, governance, sanctifying and teaching

\section{Bevezetés}

A római birodalom igazgatási rendszere alapvetően öt elemet tartalmazott: külügy, belügy, pénzügy, igazságügy és hadügy. ${ }^{3}$ A szociális kérdések nem képezték az antik államigazgatás klasszikus területét. Később a felvilágosult abszolutizmus korában kiadták a jelszót: közérdek akár a köz ellenében is. Sokan ezért a jóléti állam születését annak a szociális hálónak a kialakításával kapcsolják össze, amely megtalálta a helyes egyensúlyt a polgárok öngondoskodása és a szükséges állami beavatkozás között. Az állam létezése szempontjából azonban klasszikusan a terület, a lakosság és ezek fölötti főhatalom jelenti az állam létezésének conditio sine qua non-ját, ${ }^{4}$ és nem a ",szociális gondoskodás”. Az úgynevezett „jóléti vagy szociális államban” hangsúlyos a szociális gondoskodás, amely meghatározott köz- és államigazgatási szerveken keresztül történik. A történelem azonban azt bizonyítja, hogy az állam szociális gondoskodás nélkül is létezik. Az egyház természetétől azonban éppen az lenne idegen - ha az (szociális vagy jóléti) államhoz hasonlóan élesen elkülönülne egy szociális szegmens. Ez ugyanis azt sugallaná, hogy az egyházban - kizárólag - ez a hivatalegyüttes felel a szeretet tetteinek az előmozdításáért, amíg más hivataloknak ezen a területen nincs felelőssége. Mindezzel nem vitatjuk a modern állam igyekezetét a szociális szféra területén, de látni kell, hogy az alapvetően más kormányzati logika alapján épül fel.

A katolikus egyház esetében éppen fordított jelenségnek lehetünk tanúi. Az egyház igazgatási rendszerében ugyanis marginálisnak tünnek azok az intézmények, amelyek a „szociális” területekért felelnek. Elkülönült szegmensként - a megszentelés, a tanítás és a kormányzás mellett - a modern állammal szemben a „szociális ágens” nem jelenik meg. Továbbá mind a Római Kúria, mind a részegyházak hivatalai között arányaiban alacsony azoknak a hivataloknak a száma, amelyek kifejezetten a szegénygondozásért vagy a társadalom perifériájára került csoportokért felelnek. Mégis az egyház az alapító példája és utasítása alapján „gyógyítsatok betegeket, támasszatok föl halottakat, tisztítsatok meg leprásokat, ủzzetek ki ördögöket! Ingyen kaptátok, ingyen

3 Lörincz Lajos: A közigazgatás alapintézményei. Budapest, HVG-ORAC, 2010. 27-28.

4 Igaz ugyan, hogy a közjó megvalósítása a „jó kormányzás” alapküldetése, de azt nem vitathatjuk, hogy amennyiben az állam ezt nem valósítja meg, azzal megszűnne létezni. Erről átfogó bemutatást ad: Frivaldszky János: Jó kormányzás és a közjó, politikai és jogfilozófiai szempontból. Budapest, Pázmány Press, 2016. 
adjátok" (Mt 10,7), egész küldetését meghatározza a karitatív szeretet. A karitatív szeretet a három ág mellett külön nincs nevesítve, de jelentősége miatt az átsugárzik mind a kormányzó, mind a megszentelő, mind a tanító küldetésre. ${ }^{5}$ Sőt a karitatív szeretet egyfajta összekötő kapocs is az említett három ág között. Lehetetlen az egyház kormányzati, megszentelő vagy tanító küldetéséről beszélni anélkül, hogy az egyben ne lenne kapcsolatban a karitásszal. A karitász az egyház hármas tevékenységében való egyetemes megjelenése miatt el is mosódnak a határok: sokszor a szeretet tetteinek konkrét megnyilvánulása egyszerre tartozik a tanító, a megszentelő vagy a kormányzati tevékenységhez. A karitász rendkívül sokszínű az egyház életében, ezért képtelenség is minden területét egy tanulmányban lefedni. ${ }^{6}$

Már ebből látszik, hogy az állammal szemben az egyháznak conditio sine qua nonja az irgalmas szeretet alkalmazása. Sőt nem túlzás Salvatore Berlingo általános kánonjogi monográfiájának a címe: Igazságosság és szeretet az egyház működésében.7 A szerző a címmel is jelzi, hogy a szeretet az egész kánonjogi rendszerben a legkülönbözőbb szabályozási területeken, az általános normáktól a szentségi jogi részen keresztül az egyház hierarchikus felépítéséig, az eljárás-, a büntető- és a vagyoni jogi részekig mindent átjár. Olyan jogi rendszert, amelyben nem jelenik meg az igazságosság, nem lehet jogrendszernek nevezni, amelyben pedig nem jelenik meg a szeretet, azt nem lehet kánonjogi (jog)rendszernek nevezni. ${ }^{8}$ Carlos José Errázuriz pedig ennek kapcsán szemléletesen megjegyezi, hogy a szeretet alapparadigmája sokkal mélyebben jelen van az egyházban, mint hogy azt csak az egyház „operatív” müködéséhez kapcsoljuk. ${ }^{9}$ Az egyházi tanítóhivatal szintjén XVI. Benedek az Intima Ecclesiae natura kezdetű motu propriójában pedig úgy fejezte ezt ki, hogy a szeretetszolgálat az egyház konstitutív eleme. ${ }^{10}$

5 Alfred Hierold: Handbuch des katholischen Kirchenrechts. In Joseph Listl - Heribert Schmitz (szerk.): Handbuch des katholischen Kirchenrechts. Regensburg, Pustet, 1999. 1028-1032.

6 Ezt jól szemlélteti a római Santa Croce Egyetem konferenciakiadványa, amely több mint 500 oldalon keresztül és majd 20 tanulmányban vizsgálja a karitász jelenlétét az egyház életében. Jesús Miñambres: Organizzazione gerarchica della Chiesa e servizio della carità. In Jesús Miñambres (szerk.): Diritto canonico e servizio della carità. Milano, Giuffrè, 2008. 243-263. Bár monumentális és sokoldalú munkáról van szó, de még ez sem fedi le az összes területet.

7 Salvatore Berlingò: Giustizia e carità nell'economia della Chiesa. Contributi per una teoria generale del diritto canonico. Milano, Giappichelli, 1991.

8 Chiara Minelli: Diritto canonico e diritto civile nell'impostazione della iniziative di carità. In Jesús Miñambres (szerk.): Diritto canonico e Servizio della carità. Milano, Giuffrè, 2008. 321-335.

9 „[...] Per questo motivo preferisco parlare del servizio della carità nella Chiesa, anziché della Chiesa, giacché quest'ultimo modo di esprimersi può essere interpretato in modo indebitamente restrittivo, come si prendessero in considerazione unicamente le iniziative di carità conesse in vari modi alla Chiesa in quanto istituzione." Carlos José Errázuriz: La dimensione giuridica del servizio della carità (diakonia) nella chiesa. In Jesús Miñambres (szerk.): Diritto canonico e Servizio della carità. Milano, Giuffrè, 2008. 170-171.

10 „Caritatis etiam ministerium pars est constitutiva Ecclesiae missionis et irrenuntiabilis est expressio propriae ipsius essentiae." Benedictus XVI: Litt. Ap. MP. Intima Ecclesiae natura. Acta Apostolicae Sedis, 104. (2012), 11. 996-1004. 996. 
A jelenlegi pápa megnyilatkozásai, a kúriareform, a diplomáciai testület új pozicionálása és a katolikus egyház válságkezelésben való részvétele egyben azt is jelzi, hogy a katolikus egyház - a Szentszék irányításával nemcsak a szegénygondozás helyi szintủ enyhítésében, hanem globális szinten, a tág értelemben vett biztonsági kihívások kezelésében is helyet kér magának. Ebben a tanulmányban ennek fényében arra keresem a választ, hogy a karitatív szeretet alapítótól származó példája és utasítása hogyan érvényesül a hármas - kormányzás, megszentelés és tanítás - küldetés területén. Ferenc pápa az Evangelii gaudium kezdetủ apostoli buzdításban kánonjogi szempontból is meghatározó kijelentést tett: „Az Egyház számára a szegényekkel való törődés elsődlegesen teológiai kategória, megelőzve minden kulturális, szociológiai, politikai vagy filozófiai kategóriát." ${ }^{11}$ Amennyiben a szegényekkel való törődés valóban teológiai fogalom, akkor a szegénygondozásnak a kánonjogi rendszerben is manifesztálódnia kell. A kánonjog ugyanis a teológia szolgálatában áll. Ez igaz mind az egyetemes egyházra, mind a részegyházra, mind a regionális, mind a globális biztonság előmozdítására.

Ez utóbbi kapcsán hangsúlyozni kell, hogy az egyház nemzetközi válságkezelésben való jelenléte ugyanis alapvetően nem (biztonság)politikai megfontolásokra (bár kétségtelenül a szempontok között ez is megjelenik, például keresztények biztonsági helyzetének javítása) ${ }^{12}$ vezethető vissza. Inkább arra az egyetemes küldetésre alapozódik, amellyel az alapító ruházta fel. Eltekintve a kérdés nemzetközi jogi aspektusától, mármint hogy a Szentszék (illetve a Vatikán) a nemzetközi jog alanyaként jogosult a nemzetközi viszonyok értékelésére, ${ }^{13}$ küldetését - legalábbis az egyház önreflexiója

11 Franciscus pp: Adhort. Ap. Evangelium Gaudium. Acta Apostolicae Sedis, 105. (2013), 11. 10191138. 1103. Lásd még: Jean Laffitte: Amore e giustizia nell'enciclica Deus Caritas est: prospettiva teologica. In Jesús Miñambres (szerk.): Diritto canonico e Servizio della carità. Milano, Giuffrè, 2008. 6-18.

12 Lóránd, Ujházi: The Crisis Management of the Apostolic Holy See, or the Achievements of "Soft Power" in Defence of Christian Communities. In Kaló, József - Ujházi, Lóránd (szerk.): Budapest Report 2018 On Christian Persecution. Budapest, Szent István Társulat, Dialóg Campus, 2018. 207-215.

13 Orlando Antonini: The Diplomatic Activity of the Holy See. Communication, 12. (2015), 2. 5-16.; Louis Duchesne: The Beginnings of the Temporal Sovereignty of the Popes. New York, Benziger, 1908.; Robert Graham: Vatican Diplomacy: a Study of Church and State on the International Plane. New York, Princeton University Press, 1959.; Eric Hanson: The Catholic Church in World Politics. New York, Princeton University Press, 1987.; Gaetano Arangio-Ruiz: On the Nature of the International Personality of the Holy See. Revue Belge de Droit International, 29. (1996), 2. 355-369.; John R. Araujo: The International Personality and Sovereignty of the Holy See. The Catholic University Law Review, 50. (2001), 2. 292-336.; Mariano Barbato: A State, a Diplomat, and a Transnational Church. Perspectives, 21. (2013), 2. 27-48.; Matthew Bathon: The Atypical International Status of the Holy See. Vanderbilt Journal of Transitional Law, 34. (2001), 3. 597-632.; R. John Morss: The International Legal Status of the Vatican/Holy See Complex. European Journal of International Law, 26. (2015), 4. 927-946.; Edward Gratsch: The Holy See and the United Nations 1945-1995. New York, Vantage Press, 1997.; Finn Seyersted: Jurisdiction over Organs and Officials of States, the Holy See and Intergovernmental Organisations. The International and Comparative Law Quarterly, 14. (1965), 1. 31-82.; Alan Chong - Jodok Troy: A Universal Sacred Mission and the Universal Secular Organization: The Holy See and the United Nations. Politics, Religion, and Ideology, 12. (2011), 3. 335-354. 
alapján - az alapító legfóbb felebaráti szeretetparancsára vezeti vissza (Mt 22,37-40). Ennek sajátos vetülete a legkiszolgáltatottabbak irányába való segítés: „Amit a legkisebb testvéreim közül eggyel is tettetek, nekem tettétek" (Mt 25,40). Továbbá a katolikus egyház a nemzetközi viszonyok alanyaként nemcsak a keresztény vagy a katolikus többségủ régiók, hanem az egész világon zajló konfliktusok áldozataiért is felemelheti a szavát. Ez ismételten nemcsak a Szentszék nemzetközi jogalanyiságával, hanem teológiai szempontokkal is összefüggésben áll: „Krisztus emberré lett, bizonyos természetfölötti szolidaritással egy családdá tette, és magához kapcsolta az egész emberiséget, a szeretetet pedig tanítványai ismertető jegyévé rendelte" (Apostolicam Actuositatem - AA 9).

Bizonyos szempontból a Katolikus Egyház „kegyelmi” időszakban van. Talán soha nem állt ennyire a biztonsági, politikai és kulturális realitások talaján a történelem folyamán, mint jelenleg. A II. Vatikáni Zsinat, az azt követő pápai és szentszéki dokumentumok - beleértve a hatályos Egyházi Törvénykönyvet is - birtokában az egyház nem az események után fut. Az állammal, a nemzetközi szervezetekkel való együttmủködés közjogi szabályozása, a biztonsági helyzet naprakész monitorozása és értékelése lehetővé teszi, hogy eredeti hármas küldetését a karitász jegyében a jelenlegi válságok enyhítése érdekében használja fel. A Zsinat és az azt követő pápák egyre inkább olyan körülményeket hagytak utódaikra, hogy az emberiség nagy válságaira reflektálhassanak.

\section{A karitatív szeretet alapelve a kormányzati tevékenység területén}

Az egyház - bár kétségtelenül hordoz szinodális elemeket, de - lényegéből fakadóan hierarchikus közösség. Így a szeretet tetteire vonatkozó alapelveknek a hierarchia egyházkormányzati tevékenységében kell kézzelfoghatóvá válnia. ${ }^{14} \mathrm{~A}$ jogalkotó számos fórumon nyilatkozott arról is, hogy a szeretet tetteinek alkalmazása az a terület, ahol a laikus Krisztus-hívők eminens módon működhetnek együtt a hierarchiával. ${ }^{15}$ Az irgalmas szeretet alkalmazása nem a történelmi vagy a biztonságpolitikai helyzet

14 Salvatore Berlingò: Dal mistero al ministero: l'ufficio ecclesiastico. Ius Ecclesiae, 5. (1993), 1. 91-120.

15 A laikus Krisztus-hívőkről szóló Christifideles laici kezdetű apostoli buzdítás: „Ezen az úton nagyszámú, önmagát serényen elkötelező világi hívővel találkozunk, akik társadalmi és politikai téren a legváltozatosabb intézményes formákban vagy önkéntesen még a legszegényebbek szolgálatára is szentelik magukat.” n. 6. Illetve még határozottabban a 41. pontban: „A társadalom szolgálata sokféle módon juthat kifejezésre és valósulhat meg: vannak önkéntes egyéni és intézményes kezdeményezések az egyes személynek nyújtott segítségtől kezdve a személyek sokféle közösségének támogatásáig. Az egész Egyház, mint ilyen, közvetlen meghívást kap a szeretetszolgálatra: [...] Az Egyház ezért különösen becsüli a könyörülő jóságot a szűkölködők és a betegek iránt, a karitatív tevékenységet és a kölcsönös segítségnyújtást, melyek a mindenfajta emberi ínség enyhítésére szolgálnak." „Az irgalmasság testi és lelki cselekedeteinek régi és mindig új formáiban megmutatkozó felebaráti szeretet lényeges eleme a világ keresztény szellemủ átformálásának, ami a világi Krisztus-hívők sajátos feladata." Ioannes Paulus PP. II: Esort. ap. postsinodale. Christifideles laici. Acta Apostolicae Sedis, 81. (1989), 4. 393-521., 402-403., 470-471. 
által előállt, a kihívásokra való akár szükséges egyházi válaszlépés. Az alapító utasítása alapján állandó elem. A Gaudium et spes kezdetű zsinati konstitúció az Egyházról a mai világban már a bevezetőben megfogalmazza, hogy az Egyház bensőséges kapcsolatban áll az emberiséggel. ${ }^{16}$ Ebben a tekintetben az egyház nemhogy nem maradhat érzéketlen sem a globális, sem a regionális biztonsági kihívások irányába, hanem kötelezettségének tekinti a szegények, az éhezők, a betegségek, a háborúk áldozatainak felkarolását. ${ }^{17}$

Az egyház vezetés-irányításának pásztori beállítottsága feltételezi az emberiség globális problémái iránti érzékenységet. Az egyház ezt az alapbeállítottságát a történelmi és a biztonsági helyzetet figyelembe véve alkalmazza a kormányzás, a megszentelés és a tanítás területén. Találóan jegyzi meg Salvatore Berlingò, hogy a hierarchia minden szintjét a püspökök testületétől, a római pápa hivatalán, az egyetemes zsinaton, a római kúria dikasztériumain keresztül a pápai követekig, az egyházmegyék és a tartományok irányításáig, a plébániai szintig át kell, hogy járja az irgalmas szeretet. Ezért az egyes egyházi hivatalok vonatkozásában nem kell minden esetben külön említeni, hogy az adott hivatal részt vesz a szeretet tetteinek előmozdításában. Amennyiben csak azoknak az egyházi hivataloknak és szervezeteknek tulajdonítanánk szerepet a karitatív szeretet terén, amelyeknek a profiljában vagy a múködését szabályozó joganyagában, illetve a szabályzatában az ilyen jellegủ tevékenységre konkrét utalás történik, az az egyház felfogásától idegen jogpozitivista megközelítés lenne. ${ }^{18} \mathrm{Az}$ első közösségekben például minden különösebb szabályozás és terv nélkül, „spontán” módon fordultak a szegények felé (2Kor 9,13-14, 2Kor 8,10; ApCsel $2,44-45 ; 4,32-35)$. Ez nem jelenti, hogy ne lett volna szükséges az irgalmas szeretet tetteinek később szabályozott keretet adni. Az egyház első századi spontaneitása azonban arra utal, hogy a karitász olyan mélyen gyökerezik az egyház életében, hogy az már (az egyébként szükséges) jogi szabályozás és intézményesülés előtt megjelent.

Az egyház intézményesülésével a szegénygondozás is kereteket öltött, majd az intézmények jogi szabályozást kaptak. Tekintve, hogy az egyház hierarchikus közösség, érthető, hogy a jogalkotó a hierarchia egyes szereplői kapcsán konkrétan megfogalmazza, hogy azok hogyan kapcsolódnak a szeretetszolgálathoz. ${ }^{19}$ Adolf von Harnack

16 „Az öröm és remény, a gyász és szorongás, mely a mai emberekben, főként a szegényekben és a szorongást szenvedőkben él, Krisztus tanítványainak is öröme és reménye, gyásza és szorongása, és nincs olyan igazán emberi dolog, amely visszhangra nem találna szívükben. A tanítványok közössége ugyanis emberekből, sőt Krisztusban egységet alkotó emberekből áll, akiket a Szentlélek irányít az Atya országa felé vezető zarándokúton, és megkapták az üdvösség hírét, hogy mindenkinek elmondják. Ezért e közösség az egész emberi nemmel és annak történelmével valóban bensőséges kapcsolatban érzi magát." (GS 1.)

17 Francesco Missaglia: Contenuto giuridico della pastoralità nella Chiesa del Vaticano II. Diritto e religione, 1. (2006), 1-2. 104-124.

18 Errázuriz (2008) i. m. 171. (9. lj.)

19 Orazio Condorelli: Carità e diritto agli albori della scienza giuridica medievale. In Jesús Miñambres (szerk.): Diritto canonico e Servizio della carità. Milano, Giuffrè, 2008. 41-92.; Carlo Pioppi: Il servizio della carità nella storia della chiesa: tra creatività e adeguamento ai mutamenti sociali. In Jesús Miñambres (szerk.): Diritto canonico e Servizio della carità. Milano, Giuffrè, 2008. 105-144. 
megjegyzi, hogy a harmadik századra már megkülönböztethető az a karitász, amelyet az egyén végez, és a karitász, amelyet az egyház intézményes keretek között teljesít. ${ }^{20}$ Ez ma sincs másképp. Amellett, hogy keresztségéből származóan minden Krisztushívőnek kötelessége az egyház ügyén, így annak szeretet tettein dolgozni (208. kánon, a továbbiakban: k.), az egyház egyes nevesített intézményei szervezett keretek között végzik ezt a tevékenységet.

Mivel a legfőbb kormányzati hatalom a római pápa kezében összpontosul, elvárható, hogy a szeretet tetteinek gyakorlásában is élen járjon. A hatályos törvénykönyv a római pápa kormányzati hatalmáról szóló bevezető kánonban jelzi (331. k.), hogy „a pápa közvetlen, egyetemes, teljes és legfőbb hatalmát az egyházban mindig szabadon gyakorolhatja". Ugyanez a kánon azonban a péteri címek felsorolásánál említi, hogy a pápa az egész egyház „pásztora”. Az evangéliumi alapokkal (Jn 10,11; Mt 15,24; Mt 20,28) rendelkező jó pásztor kifejezést a jog régtől magáévá tette, és integrálta az egyházkormányzati tevékenységre vonatkozó joganyagba. Így a hatályos jogból akár arra is lehet következtetni, hogy a kormányzati hatalom szabad gyakorlásának még a pápa esetében is van határa: igaz, inkább teológiai, mintsem jogi, az pedig a pásztori minőséghez való hűség. ${ }^{21}$ A pásztor ugyanis nem pusztán kiegészítő, hanem lényegi attitűdje az egyházkormányzati tevékenységnek, a legszorosabban kapcsolódik a „caritas” fogalmához és annak életre váltásához. ${ }^{22}$

A jogi szövegekben ritkábban használt, de a római pápa „hivatalára” vonatkozóan ugyancsak nagy hagyományokkal rendelkező kifejezés a servus servorum Dei, Isten szolgáinak szolgája. Ez a kifejezés is a pápa kormányzati hatalmának szolgáló aspektusára világít rá. ${ }^{23}$ A Nagy Szent Gergely pápára (590-604) visszavezethető szófordulatot - a pápák sokáig nemcsak magukra, hanem a többi püspökre is alkalmazták. ${ }^{24}$ A kormányzati hatalom teológiai megközelítése szempontjából nyilván nem helytelen akár az összes püspök - sőt minden pap vagy akár Krisztus-hívő - ilyen megnevezése. Minden kereszténynek hivatása ugyanis, hogy szolgálja Istent a felebarátban (Róm 6,13; 12,11; 14,18; Róm 5,17-21; 2Tim 2,12). A titulus a római pápa vonatkozásában való hangsúlyozása még inkább kiemeli, hogy a legfőbb kormányzati hatalom gyakorlásának a szolgálat szellemében kell történnie. Nagy Szent Gergely pápa még pápasá-

20 Adolf von Harnack: Mission und Ausbreitung des Christentums in den ersten drei Jahrhunderten. Leipzig, 4. Ed. [1902] 1920.

21 Knut Walf: Commentary on canon 331. In John Beal - James Coriden - Thomas Green (szerk.): The New Commentary on the Code of Canon Law. New York, Paulist Press, 1998. 481.; Eduardo Molano: Commentary on canon 331. In Ángel Marzoa - Jorge Miras - Rafael Rodriguez-Ocana (szerk.): Exegetical Commentary on the Code of Canon Law. Toronto, Wilson \& Lafleur, 2. köt. (2004), 1. 592-593.

22 Marcello Semeraro: Il ministero episcopale alla luce della ecclesiologia di comunione: visone sintetica della esortazione ap. Pastores gregis. In Arturo Cattaneo (szerk.): L'esercizio dell'autorità nella chiesa. Riflessioni a partire dall'esortazione apostolica. Pastores Gregis. Venezia, Marcianum Press, 2005. 11-23. 15-16.

23 Wilhelm Levison: Zur Vorgeschichte der Bezeichnung Servus servorum Dei. Zeitschrift der Savigny-Stiftung für Rechtsgeschichte. Kanonistische Abteilung, 6. (1916), 1. 384-386.

24 Nagy Szent Gergely: Patrologia Latina.(P. L). LXXV, 87. 
ga előtt kezdte használni a címet, a pápai kancelláriába pedig részben a konstantinápolyi pátriárkai udvarban tapasztalt címkultusz ellensúlyozására vezette be. ${ }^{25}$

Tekintve, hogy az egyház hierarchikus közösség, a legfőbb hatalom gyakorlásának ilyen jellegű orientációja átsugárzik az egész hierarchikus közösségre. Ezt sajátosan szemlélteti, hogy a pápát kormányzati hatalmában segítő Római Kúria működését jelenleg még szabályozó Pastor Bonus ${ }^{26}$ kezdetű apostoli konstitúció bevezetője a kormányzati hatalom általános bemutatásánál a pápai címek közül fontosnak tartja kiemelni, hogy a pápa servus servorum Dei. Sőt ugyanitt a konstitúció kiemeli: a római püspök „vezetője a szeretett tetteinek, és a szeretet tevékenység szolgálatában áll”. ${ }^{27}$ Jesús Miñambres rámutat, hogy ennek ellenére a pápa kormányzati hatalmát bemutató szakirodalomnak csak töredéke tér ki a pápai hivatalt szubsztanciálisan meghatározó szolgáló szeretet alapparadigmájára. ${ }^{28}$

A római pápa tanítóhivatali megnyilatkozásai sajátos és egyedülálló módon mozdítják elő a szeretet tetteit. Nem lehet elmenni azok mellett az enciklikák mellett, amelyek az irgalmas szeretet egyes területére vonatkoznak, mindig figyelembe véve az éppen aktuális globális és regionális társadalmi és biztonsági kihívásokat. ${ }^{29}$ Hasonlóan komoly iránymutatásul szolgálnak azok a cselekedetek, amelyekkel a pápák a legelesettebbek iránti figyelmük megható jeleit adják. A jelenlegi pápa különösen nagy figyelmet szentel az ilyen jellegű szeretettetteknek (nagycsütörtöki lábmosás, palota szegényeknek való átengedése, zuhanyzó építése a hajléktalanoknak, a menekültek meglátogatása stb.). Ez nem pusztán a szolidaritás kifejeződése, hanem

25 Karl Schmitz: Ursprung und Geschichte der Devotionsformeln bis zu ihrer Aufnahme in die fränkische Königsurkunde. Stuttgart, Kirchenrechtliche Abhandlungen, von Ulrioh Stutz, 1913.

26 „Id vero ad singulos Episcopos in propria cuiusque particulari Ecclesia spectat; attamen tanto magis ad Romanum Episcopum pertinet, cuius ministerium Petrianum in universalis Ecclesiae bonum utilitatemque procurandam incumbit: Romana enim Ecclesia praesidet »universo caritatis coetui « ideoque caritati inservit. Ex hoc potissimum principio processerunt vetusta illa verba "Servus Servorum Dei«, quibus Petri Successor denominatur atque definitur." Johannes Paulus II: Const. Ap. Pastor Bonus. Acta Apostolicae Sedis, 80. (1988), 5. 841-934.

27 Uo.

28 Miñambres (2008) i. m. (6. lj.) 254. Pozitív ellenpéldaként idézi: Joël-Benoît D’Onorio: Le pape et le gouvernement de l'Eglise. Paris, Fleurus-Tardy, 1992.; Alberto De La Hera: La suprema autoridad de la Iglesia en la codificación canónica latina. Ius Canonicum, 33. (1993), 2. 515-540.

29 Leo XIII: Enc. Rerum novarum. Acta Apostolicae Sedis, 23. (1931), 5. 641-670;; Pius XI: Enc. Quadragesimo anno. Acta Apostolicae Sedis, 23. (1931), 5. 177-285.; Johannes XXIII: Enc. Mater et magistra. Acta Apostolicae Sedis, 53. (1961), 5. 401-464.; Paulus VI: Enc. Populorum progressio. Acta Apostolicae Sedis, 59. (1967), 3. 257-299.; Paulus VI: Lit. Ap. Octogesima adveniens. Acta Apostolicae Sedis, 63. (1971), 5. 401-444.; Johannes Paulus II: Enc., Laborem exercens. Acta Apostolicae Sedis, 73. (1981), 9. 577-647.; Johannes Paulus II: Ex. Ap. Post. Syn. Sollicitudo rei socialis. Acta Apostolicae Sedis, 79. (1987), 12. 513-586.; Johannes Paulus II: Enc. Centesimus annus. Acta Apostolicae Sedis, 83. (1991), 5. 793-867.; Benedictus XVI (2012) i. m. (10. 1j.). Benedictus XVI: Enc. Deus Caritas est. Acta Apostolicae Sedis, 98. (2006), 3. 217-279. Ehhez összefoglaló munka: Bernard A. Hebda: Where Canon Law Connects with Caritas: The Norms of Intima Ecclesiae Natura. A Year of Mercy Examination of Challenges to Compliance in a US Context. The Jurist, 76. (2016), 2. 339-359. 
jelzi, hogy az irgalmas szeretet a legfőbb kormányzati hatalom gyakorlásának integráns részét képezi.

A római pápát a legfőbb kormányzati hatalmának gyakorlásában a római kúria dikasztériumai segítik. A római kúria müködését szabályozó Pastor Bonus kezdetủ apostoli konstitúció az egész kúria vonatkozásában kiemeli a diakónia jelentőségét. ${ }^{30}$ II. János Pál már a konstitúció címével is jelzi, hogy az egyház legfőbb vezetés-irányítási szerve a jó pásztor Pastor Bonus szellemében jár el. II. János Pál egyébként is szerette a kormányzati hatalomhoz kapcsolódó rendelkezéseinek a címében szerepeltetni a pásztorra való utalást: így a papnevelésről szóló Pastores dabo vobis kezdetű szinódus utáni apostoli buzdításának ${ }^{31}$ vagy a Pastores gregis kezdetủ püspöki szolgálatról szóló apostoli buzdításának a címében. ${ }^{32}$ Ez utóbbi dokumentumban számos alkalommal felhívja a pápa a püspöktestvérei figyelmét, hogy a kormányzati feladataikat az irgalmas szeretet jegyében gyakorolják. Ennek legszemléletesebb összefoglalóját a dokumentum 20. pontja adja, amely a kormányzati feladatok gyakorlása kapcsán megjegyzi: „A procurator pauperum, »a szegények gondozója « mindig egyik neve volt az Egyház pásztorainak, s nekik ma is ennek kell lenniük, hogy megjelenítsék és elevenné tegyék Jézus Krisztus evangéliumának üzenetét, ami mindenki reményének alapja, s különösen azoké, akik egyedül Istentől remélhetnek emberhez méltóbb életet és jobb jövőt. A pásztorok példájától indítva kell megvalósítania az Egyháznak és az egyházaknak azt a »szegények iránti pozitív megkülönböztetést«, amit a harmadik évezred programjaként mutattam meg." ${ }^{33}$

Ami az operatív szintet illeti, Ferenc pápa a kúrián belül külön csúcsszervet - Dikasztérium az Átfogó Emberi Fejlödés Szolgálatában - hozott létre, amely a társadalmi igazságosság előmozdításában, a szegények, a menekültek gondozásában segíti a pápát a legfőbb kormányzati tevékenységében. A dikasztériumot Ferenc pápa állította fel, de ez nem jelenti, hogy az új „csúcsszerv” létrehozása előtt nem lett volna olyan központi hivatal, amely a római pápát ezen a területen támogatta. A dikasztériumba integrált négy pápai tanács a Iustitia et Pax, a Cor Unum, az Egészségügyi Dolgozók és az Elvándorlók és Úton Lévők Lelkigondozására létrehozott pápai tanácsok - igaz, más-más területen, de eleve rendelkeztek ilyen küldetéssel.

A Cor unum pápai tanács különösen jelentős szerepet töltött be a katolikus egyház nemzetközi karitatív szerepvállalásának összehangolásában. A leginkább ismert Caritas internationalis felügyelete mellett, a latin-amerikai fejlesztési projektekért

30 Johannes Paulus II: Ex. Ap. Pastor Bonus. Acta Apostolicae Sedis, 80. (1988), 7. 841-934. 893-921.

31 Johannes Paulus II: Ex. Ap. Post. Syn., Pastores dabo vobis. Acta Apostolicae Sedis, 84. (1992), 3. 657-804. A szegények szolgálatára való utalás különösen a 30. pontban jelenik meg: „A papoknak - Krisztus példája szerint, aki jóllehet gazdag volt, szegény lett, mert szeretett minket (vö. 2Kor 8,9) - a szegényeket és gyengéket úgy kell tekinteniük, mint akik különösen is a gondjaikra vannak bízva; továbbá képesnek kell lenniük arra, hogy egyszerủ és kemény életükkel tanúskodjanak a szegénység mellett azáltal, hogy a felesleges dolgoktól nagylelkűen tartózkodnak." Johannes Paulus II (1992) i. m. (31. lj.) 705-706.

32 Johannes Paulus II: Ex. Ap. Post. Syn Pastores gregis. Acta Apostolicae Sedis, (2003), 12. 825-924.

33 Uo. 852-853. 
felelős 1992-ben létrehozott Fondazione Populorum Progressio-t (alapítványt) is irányította. Jelenleg az említett szervezetek szentszéki kormányzati felügyelete az új dikasztérium feladata. II. János Pál alapítványa a Száhel-térség megsegítéséért ugyancsak a Cor Unum Pápai Tanács irányítása alá tartozott. Az alapítványt II. János Pál 1980-as Burkina Fasó-i látogatása után kezdték szervezni. A hivatalos jóváhagyásra 1984. február 22-én került sor. ${ }^{34}$ II. János Pált a Száhel-térségben tapasztalt emberi nyomorúság, az elsivatagosodás elleni küzdelem motiválta a kezdeményezés létrehozásánál. Eredetileg ez a szervezet is a Cor Unum pápai tanács alá tartozott. Meg lehet még említeni az új dikasztériumba integrált Egészségügyi Dolgozók Lelkigondozásának Pápai Tanácsa alá tartozó Irgalmas szamaritánus - Fondazione il buon samaritano - kezdeményezést is. A legelesettebbekkel, legkiszolgáltatottabb betegekkel foglalkozik, szintén leginkább az elmaradottabb régiókban. ${ }^{35}$

A Iustitia et Pax pápai tanács pedig világviszonylatban a béke, a társadalmi igazságosság előmozdítása, a szegénység, a háborúk regionális felszámolása érdekében segítette a legfőbb pásztor munkáját. Tevékenységének minőségét szemlélteti az Egyház társadalmi tanitásának kompendiuma. Elkészítésével még II. János Pál bízta meg a tanácsot, de a kiadásra már XVI. Benedek idejében került sor. ${ }^{36} \mathrm{~A}$ kompendium bemutatja az egyház elméleti tanítását mindazokban a társadalmi kérdésekben, amelyek a biztonság új típusú megközelítésében is megjelennek. ${ }^{37} \mathrm{~A}$ kompendium mélyebb elemzését adja az emberi jogok, a közjó, a gazdaság, az állam, a nemzetközi közösségek, a környezetvédelem, a terrorizmus kérdésének, vagyis olyan területeknek, amelyek a biztonság átfogó értelmezésében is helyet kapnak. ${ }^{38} \mathrm{~A}$ tanács számos egyéb munkát is megjelentetett, amely az „új típusú” biztonsági kihívásokkal foglalkozik. ${ }^{39}$

34 La Fondazione Sahel contro la desertificazione. Elérhető: www.corunumjubilaeum.va/content/corunumexpo/it/fondazioni/fondazione-giovanni-paolo-ii.html (A letöltés dátuma: 2020. 02. 19.)

35 Fondazione Il Buon Samaritano. Elérhető: www.humandevelopment.va/it/il-dicastero/fondazioni/ il-buon-samaritano.html (A letöltés dátuma: 2020. 02. 19.)

36 Igazságosság és Pápai Tanács: Az egyház társadalmi tanításának kompendiuma. Budapest, Szent István Társulat, 2007.

37 Padányi József - Földi László: Security Research in the Field of Climate Change. In Nádai László - Padányi József (szerk.): Critical Infrastructure Protection Research: Results of the First Critical Infrastructure Protection Research Project in Hungary. Zürich, Springer, 2016, 79-90.

38 Resperger István: A válságkezelés kicsit másképp. Nemzetbiztonsági Szemle, 4. (2016), 3. 28-48. (Különösen a 42. oldal ábrái.)

39 A teljesség igénye nélkül a Igazságosság és Pápai Tanács néhány publikációja a szeretet és a társadalmi igazságosság előmozdítása kapcsán. A vallások és a humanitárius jog kapcsolatáról: Humanitarian Law and Religions. Città del Vaticano, Libreria Editrice Vaticana, 2009.; A raszszizmus elleni fellépésről: La Chiesa di fronte al razzismo: Per una società più fraterna. Città del Vaticano, Libreria Editrice Vaticana, 1988.; A fegyverzetleszerelésről: Prospettive per un disarmo integrale. Città del Vaticano, Libreria Editrice Vaticana, 2008.; Emberi jogok védelméről: Diritti umani dei detenuti. 2007.: Az igazságosság és béke kapcsolatáról: Justice and Peace: An Ever Present Challenge. Città del Vaticano, Libreria Editrice Vaticana, 2004.; A humanitárius segítségnyújtásról és a katonai lelkészekről: Diritto Umanitario e Cappellani Militari. Città del Vaticano, Libreria Editrice Vaticana, 2003.; A Szentszék és a nemzetközi szervezetek kapcsolatáról: Words that Matter: The Holy See in Multilateral Diplomacy. New York City, The Path to Peace Foundation, 2003.; Az éhínség enyhítéséről: Atti del Seminario di Studio del Pontificio Consiglio della Giustizia 
A kompendium érdeme azonban, hogy röviden, frappánsan, egy helyen értékeli a biztonsági komplexben felvetett kihívások jelentős részét. A kompendium jól példázza, hogy a biztonság átfogó értelmezésével jelentkező kihívásokat az egyház sajátos személyközpontú reflexióval közelíti meg.

A római kúria más szervezetei kapcsán a szervezet profiljának megfelelően említésre kerülhet a szolgáló szeretet. A Világiak Pápai Tanácsa kapcsán az említett konstitúció megjegyzi, hogy a tanács illetékes, hogy a laikusokat a karitatív munkában segítse. $^{40}$

A Római Kúriát szabályozó Pastor Bonus kezdetű apostoli konstitúció egyetlen, az utolsó záró cikkelyében foglalkozik az Apostoli Alamizsnahivatal (Elemosineria Apostolica) müködésével. ${ }^{41}$ A „Szentatya Segélyszolgálatára” való befejező utalás azonban keretet alkot a konstitúció bevezetőjével, amely a pápai kormányzati hatalom szolgáló jellegét emeli ki. A lezárásban pedig konkrétan megjelenik a „Szentatya Segélyszolgálata". ${ }^{42}$ Egyes vélemények szerint a Ferenc pápa által meghirdetett kúriareform lezárása után a dikasztérium még jelentősebb helyet fog elfoglalni a központi hivatalok rendszerében. ${ }^{43}$

A pásztor karakter és annak teológiai vonatkozása nemcsak a római pápára és a római kúriára, hanem a megyéspüspökre vonatkozó joganyagon is átsugárzik. A Kódex azonban mindössze néhány helyen jelzi, hogy a megyéspüspök köteles szeretetben, alázatosságban és életének egyszerűségében példát adni (387. k.). Máshol a katolikus egyházzal teljes közösségben nem lévőkkel kapcsolatban kéri, hogy viseltessen emberséggel és szeretettel (383. k. 3. \$). XVI. Benedek az Egyházi Törvénykönyv ezen hiátusát kifejezetten "lacuna legisnek”, joghézagnak tekintette, ${ }^{44}$ amelyet pápasága alatt igyekezett orvosolni. Más jogforrások azonban már régebben is - a Kódexnél erőteljesebben - jelezték, hogy a püspök kormányzati beállítottságát szubsztanciálisan meghatározza a szolgáló szeretet. A püspökszentelés előtt a püspöki szolgálat kapcsán megkérdezik a jelöltet: akar-e „az Úr kedvéért jóságos és irgalmas lenni a szegények és a hontalanok és minden szükséget szenvedő iránt”.45

e della Pace, Roma, Edizioni ART, 2004.; A fegyverkereskedelemről: Il commercio internazionale delle armi. Una riflessione etica. Città del Vaticano, Libreria Editrice Vaticana, 1994.; A föld javainak igazságosabb elosztásáról: Per una migliore distribuzione della terra. La sfida della riforma agraria. Città del Vaticano, Libreria Editrice Vaticana, 1997.; A menekültkérdésről: Refugees: A Challenge to Solidarity. New York, The Center for Migration Studies of New York, 1994.

40 Johannes Paulus II (1988) (26. lj.) i. m. 894.

41 Uo. 912.

42 „Eleemosynaria Apostolica opus adiumenti pro Summo Pontifice exercet erga pauperes ac pendet directe ex Ipso." Uo. 912.

43 Nicola Graziani: Come cambierà la Curia con la riforma voluta da Papa Francesco. 2020. Elérhető: www.agi.it/cronaca/news/2020-02-13/riforma-curia-papa-francesco-7036811/ (A letöltés dátuma: 2020. 05. 04.)

44 Benedictus XVI. (2012) i. m. (10. lj.) 996-997.

45 Istentiszteleti Kongregáció: Pontificale Romanum De ordinatione episcopi. Città del Vaticano, Typis Polyglottis Vaticanis, 1990. 43. 
A Püspöki Kongregáció Apostolorum Sucessores kezdetű utasítása a püspökök önazonosságára és küldetésére vonatkozóan már az átalános bevezetőben kiemeli, hogy a püspök Krisztus mintájára pásztor és a lelkek védelmezője. ${ }^{46} \mathrm{~A}$ dokumentum a püspöki szolgálatot a jó pásztor karakteréhez hasonlítja, amelynek alapbeállítottsága a jóság, a kegyelem és a nagyvonalúság. Az utasításban számtalan helyen megjelenik a kiszolgáltatottakkal való együttérzés mint a püspöki karakter meghatározó eleme, de kifejezetten a hármas küldetés vonatkozásában az utasítás kimondja: a püspök a hármas küldetést a jó pásztor példája szerint gyakorolja. ${ }^{47}$

\section{A karitász szerepe az egyházi jogalkotásban, végrehajtásban és bíráskodásban}

Tekintve, hogy az egyházkormányzat rendszerében a jogalkotást, a végrehajtást és a bíráskodást megkülönböztetjük ugyan, de a világi jogi rendszerektől eltérően a gyakorlásukat élesen nem választjuk el, ildomos a szeretet tetteinek a megnyilvánulásainál is együtt vizsgálni a három ágat. ${ }^{48}$ Kisebb hangsúlyeltolódás azért megfigyelhető. A három ág közül inkább a végrehajtás és a jogalkotás területén érhető tetten a karitász, amíg a bíráskodás vonatkozásában direktben ez kevésbé figyelhető meg. Ez érthető, hiszen az egyházi intézmények, amelyek a szeretet tetteit végrehajtják, eleve jogszabályi környezetben működnek, amely feltételezi a jogalkotó tevékenységét. A szervezetek mủködése, ellenőrzése stb. pedig a végrehajtás területéhez tartozik. Ehhez képest a jogszolgáltatás kevésbé érintett.

Az úgynevezett hatalmi ágak között általában a jogalkotást szokás először vizsgálni. A klasszikus francia megközelítésben ugyanis a másik két hatalmi ág csak végrehajtja a jogalkotó akaratát. Ez elsődlegességet biztosít a jogalkotásnak. Ugyanakkor - amennyiben a szent szövegek utasító, jogi aspektusától eltekintünk (amikor Jézus utasítást ad a tanítványoknak a szeretet tetteire) - az irgalmasság tettei először a praxisban, a tág értelemben vett „igazgatásban” jelentek meg. Az Apostolok Cselekedete beszámol arról, hogy a tanítványok hét diakónust választanak ki a szegények gondozására (ApCsel 6,2-3,5-6). Ez az első hivatalalapítás. A Tizenkettőt az Úr jelöli ki - hivataluk az ő szándékára megy vissza. A hét diakónus feladatát azonban már az apostolok határozzák meg. Tág értelemben ugyan, de az első hivatalalapítás a karitatív szeretet gyakorlásához kapcsolódik. A jogalkotás már csak ezt követően emeli be a jogi szövegekbe akár általánosságban, akár az egyes egyházi hivatalok gyakorlása kapcsán a szeretet tetteinek szempontjait.

46 Instr. Apostolorum successores. 2004. Elérhető: www.vatican.va/roman_curia/congregations/cbishops/documents/rc_con_cbishops_doc_20040222_apostolorum-successores_en.html (A letöltés dátuma: 2020. 03. 05.)

47 Uo.

48 Gianfranco Ghirlanda: Potestà di governo. Potestas Regiminis. In Corral Carlos Salvador - Velasio De Paolis - Gianfranco Ghirlanda (szerk.): Nuovo dizionario di diritto canonico. Torino, San Paolo, 1993. 802-803. 
XVI. Benedek ezt az első „hivatalalapítást” a Deus Caritas est kezdetű enciklikájában az egyház későbbi intézményesülése és az ehhez kapcsolódó jogi keretek kiépítése szempontjából meghatározónak tekinti. „[A] szociális szolgálat, melyet (a hét diakónusnak) végezniük kellett, egészen konkrét, ugyanakkor teljesen lelki szolgálat, s ezért a hivataluk valóban lelki hivatal volt, mely az Egyház egyik lényeges feladatát - a rendezett felebaráti szeretetet - valósította meg. E hét fős csoporttal a »diakonia « - a felebaráti szeretet közösségi és rendezett szolgálata - beépült az Egyház alapvető struktúrájába." ${ }^{49} \mathrm{Ez}$ alatt az egyházi struktúra alatt az egész egyházat, vagyis annak minden szintjét értjük: a plébániai, az egyházmegyei, az országos és a nemzetközi szintet is. ${ }^{50}$ A diakónusok, akik a püspöki kézfeltételben küldetésüket szolgálatra kapják, egyébként a II. Vatikáni Zsinat után újra kiemelten képviselik az egyház hármas küldetését átjáró szolgáló szeretet üzenetét. A Zsinat utáni jogalkotás és kánoni szakirodalom efelől nem hagy kétséget. ${ }^{51}$

Az említett Deus caritas est kezdetü enciklika külön hangsúlyt helyez a püspökök szerepére a karitász tetteinek megvalósításában. „Az Egyház püspöki struktúrájának megfelelően a részegyházakban elsődlegesen a püspökök, mint apostolutódok felelösek azért, hogy az Apostolok Cselekedeteiben meghirdetett »program « ma is megvalósuljon." ${ }^{2}$ Emellett a püspöki konferenciák kezdeményezéseinek is van szerepe, minthogy a legtöbb országban a püspöki konferenciák rendelkeznek olyan bizottságokkal, amelyek teoretikusan foglalkoznak a társadalmi igazságosság kérdésével, illetve tipikus, hogy az egyházmegyei karitász mellett a püspöki konferencia alárendeltségében országos karitász is tevékenykedik. ${ }^{53}$

Ami a plébániákat illeti, találóan mutat rá Luis Antonio Tagle bíboros az egyik vele készített interjúban, hogy az egyház a plébániákon él. ${ }^{54}$ A legtöbb ember az egyház „igazgatásának” csak erre a szintjére lát rá. Ezért az irgalmas szeretet tetteinek a megjelenése ezen a szinten a „leghangsúlyosabb." A plébánia papsága és hívei az egyház „követei” az egyház magasabb szinten elhangzó tanításainak a gyakorlatra váltásában. Az Apostolorum Succesores kezdetű utasítás az egyházmegye papjait olyan pásztoroknak nevezi, akik segítik a püspököt a hármas - papi, tanítói és pásztori - küldetésében. ${ }^{55}$ A plébánosok pedig konkrétan részesülnek az egyház megszentelő (528. k. 2. \$), tanító (528. k. 1. \$) és kormányzati küldetésében (529. k. 1. \$, 2. \$). A Kódex egyéb-

49 Benedictus XVI. (2006) i. m. (29. lj.) 234.

50 Miñambres (2008) i. m. (6. lj.) 253.

51 Jean Beyer: Il diaconato permanente nell'attuale vita ecclesiale. Quaderni di diritto ecclesiale, 10. (1997), 2. 134-142.; Pierantonio Pavanello: La determinazione canonica del ministero del diacono permanente Quaderni di diritto ecclesiale, 10. (1997), 2. 143-159.

52 Benedictus XVI. (2006) i. m. (29. lj.) 246. Lásd még: Miñambres, Jesús: Atti Benedetto XVI. Lettera Apostolica MP. Intima Ecclesiae natura sul servizio della carità (11 novembre 2012). Ius Ecclesiae, 25. (2013), 2. 499-532.

53 Magyar vonatkozásban a Püspöki Konferencia Caritas in Veritate bizottsága, régebben Iustitia et Pax bizottság.

54. Special Interviews from Asia: Cardinal Luis Antonio Tagle. Elérhető: www.youtube.com/ watch?v=q2YqAVHgJa8 (A letöltés dátuma: 2020. 03. 05.)

55 Instr. Apostolorum successores i. m. (46. lj.) 
ként a plébánosokat is rendre pásztoroknak - méghozzá a plébániai közösség saját pásztorának nevezi $(515$. k. 1. \$). Más esetben pedig konkrétan jelzi a törvénykönyv, hogy a plébános pásztori küldetésének teljesítéséhez hozzátartozik a szegényekkel és a szenvedőkkel való különleges törődés $(529 . \mathrm{k}$. 1. \$). A pásztor tehát önmagában olyan teológiai kifejezés a plébánosra vonatkozó joganyagban, ${ }^{56}$ amely magában hordozza a plébános egyházkormányzati beállítottságának irgalmas, a szegények iránti elkötelezett krisztusi karakterét. ${ }^{57}$ Emellett a hatályos joganyag a régi joghoz képest is nagyobb hangsúlyt helyez a plébános kormányzati tevékenysége között a szegények gondozására ${ }^{58} \mathrm{~A}$ plébánia szintjén az irgalmas szeretet megnyilvánulásának számtalan oldala lehet - betegek, öregek látogatása, segélyezési programok stb. Különleges jelentősége lehet a családlátogatásoknak, ahol a plébános megismeri azokat a családokat, akik szükséget szenvednek, és a plébánia lehetőségeihez mérten segíti őket. ${ }^{59}$ Bár a szeretet tetteinek fő koordinátora a plébánia szintjén a plébános, de az irgalmas szeretet tetteinek gyakorlása kapcsán sajátosan jelenhetnek meg a laikus Krisztushívők, akik bekapcsolódnak a plébániai szegénygondozásba. ${ }^{60} \mathrm{~A}$ szegénygondozás különleges területe a hierarchia és a laikus Krisztus-hívők - sokat vitatott - egyházkormányzat területén való együttműködésének.$^{61}$ Ezt jól szemlélteti a II. Vatikáni Zsinat világi hívek apostolkodásáról szóló Apostolicam Actuositatem kezdetű dekrétuma, amely a világi hívek karitatív tevékenységének külön pontot szentel (AA 9.).

A karitatív szeretet érvényesítésében az egyházi jogalkotásnak is jelentős szerep jut. Először is a szeretet tetteit az egyház a legtöbb esetben intézményein keresztül foganatosítja. Az intézmények jogi keretek között működnek: legyenek azok az egyetemes vagy részleges jogszabályok vagy az illetékes egyházi hatóság által jóváhagyott szabályzatok (299. k. 3. \$). A szervezetek zavartalan müködéshez szükséges kérdések, mint a felépítés, a vezetés-irányítás, a felügyeleti szerv, a tagság, a jogok és a kötelezettségek a jogszabályokban kapnak keretet. De a jogalkotó feladata az is, hogy tisztázza a karitatív szeretet előmozdításán dolgozó egyházi intézmények és a hasonló profilú, más katolikus szervezetek vagy a civil intézmények közötti együttműködésre vonatkozó alapelveket. ${ }^{62}$ II. János Pál a hatályos Egyházi Törvénykönyv kihirdetésekor erre kiválóan mutatott rá: „És valóban az Egyházi Törvénykönyv teljességgel szükséges az egyház számára. Mivel az egyház felépítésében társadalmi és látható szervezet

56 Cesare Bonicelli: Il parroco come pastorale (c. 529. par.). Quaderni di diritto ecclesiale, 6. (1993), 1. 43-49.

57 Francesco Coccopalmerio: Il parroco «pastore» della parrocchia. Quaderni di diritto ecclesiale, 6. (1993), 1. 6-22.

58 Paolo Montini: Il ministero del parroco (cann. 528-529). In Docenti di diritto canonico, Associazione Canonistica Italiana (szerk.): La parrochia. Milano, Glossa, 2005. 125-148. 134-135.

59 Filippo Natale Appendino: La visita pastorale del parroco alle famiglie. Archivo Teologico, 1. (1995), 290-308.

60 Erdő Péter: A világiak munkája a plébánián. Távlatok, 12-13. (1993), 3-4. 632-640.

61 Alvaro del Portillo: Laici e fedeli nella Chiesa. Le basi dei loro statuti giuridici. Milano, Giuffré, 1999.

62 Ujházi Lóránd: Specific Apparatus of Vatican Diplomacy - Charity Organisations. Academic and Applied Research in Military and Public Management Science, 18. (2019), 1. 149-168. 
is, szabályokra van szüksége, hogy láthatóvá váljék hierarchikus és szerves struktúrája, hogy Istentől rábízott feladatoknak, különösen a szent hatalomnak és a szentségek kiszolgáltatásának gyakorlása megfelelő rendezést nyerjen, hogy a krisztushívők kölcsönös kapcsolatai szereteten alapuló igazságosság szerint alakuljanak [...].”3

Az egyházi jogalkotásnak az egyes jogintézmények jogszabályi és müködési keretének megalkotása mellett abban is szerepe van, hogy a konkrét jogszabályokban teológiai utalást tegyen az irgalmas szeretetre. Ezek az utalások teológiai motiváltságú megjegyzések, amelyekkel sajátosan jelzi a jogalkotó, hogy a legprofánabbnak tűnő jogi területek (például anyagi javak vagy társulási jog) is kapcsolódnak az egyház alapvető küldetésének, az irgalmas szeretet tetteinek a végrehajtásához. Például a jogi személyek általános bemutatásánál a jogalkotó tisztázza, hogy a jogi személyeket az egyház küldetésének megfelelő célokra hozzák létre (114. k. 1. \$), amelyek „a vallásosság, az apostoli tevékenység és akár lelki, akár anyagi vonatkozású irgalmas szeretet tetteivel kapcsolatos tevékenységek" (114. k. 2. \$).

Az úgynevezett „egyházi alkotmányjogi” résznél pedig a Krisztus-hívők kötelezettségei között említi a jogalkotó, hogy saját jövedelmükből kötelesek segíteni a szegényeket (222. k. 2. \$.). Mivel ez a kötelezettség az általános résznél szerepel, az nem csak a laikusokat és nem csak a klerikusokat, hanem az egyház minden tagját kötelezi. Mindezzel összecseng az egyház anyagi javaira vonatkozó általános szabályozás, amely az egyház anyagi javait az egyház sajátos céljainak szolgálatára rendeli (1254. k. 1. \$). A sajátos célok között pedig ott szerepel a szegényekkel szembeni segítő szeretet gyakorlása (1254. k. 2. \$). A jog itt nem egyszerűen célnak, hanem sajátos célnak nevezi az apostoli tevékenységet, különösen a szegényekkel szembeni segítő szeretetet. ${ }^{64}$ A Kódex e tekintetben követi a II. Vatikáni Zsinat koncepcióját (Lumen gentium 13; 23; Gaudium et spes 42; 69; 71; 76; Presbyterorum ordinis 17; 20 21; Perfectae caritatis 13; Christus dominus 6; 28; Dignitas humanae 4; 13; Gravissimum educationis 8; Inter Mirifica 3.): az egyház rendelkezik anyagi javakkal, azokat igazgatja vagy elidegeníti, de ez mindig céljai megvalósításához kapcsolódik, közte az apostoli munka teljesítéséhez és a szegények gondozásához. ${ }^{65}$

A Krisztus-hívőket megillető társulási jog „dogmatikai” megalapozásánál pedig hangsúlyosan jelenik meg, hogy a Krisztus-hívők társulásának a célja, - a keresztény, illetve vallásos célok mellett - a jótékony szeretet előmozdítása. A Krisztus-hívőknek így akár laikusok, akár klerikusok, joguk van, hogy a jótékony szeretet előmozdítására társulásokat alapítsanak vagy vezessenek, vagy ilyen cél érdekében összejöveteleket

63 Johannes Paulus II: Sacrae disciplinae leges. Communicationes, 15. (1983), 1. sz. 8-9. Magyarul: Erdő Péter: Az Egyházi Törvénykönyv. Budapest, Szent István Társulat, 1997. 30-46.

64 Jean Pierre Schouppe: Elementi di diritto patrimoniale canonico. Milano, Giuffrè, 1997. 11.; Velasio De Paolis: I beni temporali della Chiesa. Canoni preliminari (cann. 1254-1258) e due questioni fundamentali. In Gruppo italiano docenti di diritto canonico (szerk.): I beni temporali della Chiesa. Milano, Glossa, 1997. 9-43.

65 De Paolis (1997) i. m. (64. lj.) 17. A II. Vatikáni Zsinat és az egyház anyagi javai témakörben lásd még: Daniel Faltin: De recto usu bonorum ecclesiasticorum ad mentem Concilii Vaticani II. Apollinaris, 40. (1967), 441-442. 
rendezzenek (215. k.). Az apostoli tevékenységben való aktív részvétel - amelynek része a jótékony szeretet gyakorlása is - minden Krisztus-hívő joga és kötelessége, tekintve, hogy a keresztség szentségében mindannyian részesültek az egyház általános papi, prófétai és tanítói küldetésében (216-217. kk.). Azt megint csak a jog tisztázza, hogy a Krisztus-hívők társulása milyen feltételek mellett, milyen jogi alakzatot ölthet. Konkrétan, hogyan lehet magán- vagy hivatalos társulás, jogi személyiséggel rendelkező vagy nem rendelkező, milyen feltételek mellett viselheti a katolikus jelzőt (216. k.). Hogyan történik a szabályzat jóváhagyása vagy felülvizsgálata, az milyen kötelező elemeket tartalmazzon, milyen kapcsolatban áll a társulás az egyházi hierarchiával, hasonló profilú katolikus szervezetekkel vagy állami és társadalmi kezdeményezésekkel. ${ }^{66}$ A Krisztus-hívők karitatív kezdeményezései tényleg széles skálán mozoghatnak, lehetnek helyi, nemzeti vagy akár nemzetközi karakterủek. Találóan mutat rá azonban Luis Navarro a Krisztus-hívők társulásait és a karitász kapcsolatát taglaló tanulmányában, hogy akármilyen jogi alakzatot is ölt a Krisztus-hívők karitatív célokra létrehozott kezdeményezése - hiszen mindegyik jogi alakzatnak megvan a maga előnye -, minden esetben hangsúlyozni kell, hogy a kezdeményezéseknek természetfeletti motivációja van. A hasonló profilú állami vagy társadalmi kezdeményezésekhez képest nemcsak a "filantrópia”, hanem a krisztusi szeretet motiválja ${ }^{67}$

Hasonló szempontok mondhatók el a szerzetesrendek vonatkozásában is. A történelem folyamán számos szerzetesrend karizmájában jelent meg a szegénygondozás, a betegápolás vagy az irgalmas szeretet gyakorlásának más formája - például fogolykiváltás. ${ }^{68}$ A szerzetesrend elismerése, vezetése, tagok felvétele, elbocsátása, képzése stb. azonban jogi elöírások mentén történik. ${ }^{69}$ Még azoknak a szerzetesrendeknek az esetében is, ahol a karizmatikus alapító nagy figyelmet fordított a karitatív tettekre, de annál kevesebbet a jogi keretekre, az alapító halála után világossá vált, hogy a karitatív szeretet tetteinek a zavartalan és tökéletes végrehajtásához szükségesek a jogi keretek. Elég Assisi Szent Ferencre (1181/1182-1226) és Szent Bonaventúrára (1221-1274) gondolni. Az utóbbi az alapító karizmája és elgondolása alapján strukturális keretet teremtett a rend müködéséhez. Egyes szerzetesrendek fő tevékenysége az irgalmas szeretet egyes területeire összpontosul az alapító szándéka és a rend saját karizmája alapján. Az Egyházi Törvénykönyv azonban a megszentelt élet összes intézményeire vonatkozó közös szabályok alatt többször is említi a szeretet megnyilvánulásának jelentőségét (573. k. 1. \$; 607. k. 1. \$; 602. k.). Még ha az utalás nem is specifikusan a klasszikus karitásztevékenység vonatkozásában kerül elő, mégis jelzésértékủ, hogy a jogalkotó általában fontosnak tartotta, hogy a megszentelt élet min-

66 Del Portillo i. m. (61. lj.) 114-124.

67 Luis Navarro: Le iniziative dei fedeli nel servizio della carità. Fondamento e configurazione giuridica. In Jesús Miñambres (szerk.): Diritto canonico e Servizio della carità. Milano, Giuffrè, 2008. 193-223. 196. Idézi: Scema Decreti de Apostolatu laicorum. n. 62. 1963. IV. 22, AS III. IV. 700.

68 Georg Jelich: Kirchliches Ordensverständnis im Wandel. Leipzig, St. Benno, 1983.

69 Átfogó szerzetesjogi munka: Andres Domingo: Le forme di vita consacrata. Commentario teologico giuridico al Codice di Diritto Canonico. Roma, Ediurcla, 2005. 
den intézménye vonatkozásában jelenjen meg az irgalmas szeretet. ${ }^{70} \mathrm{~A}$ történelem azt mutatja, hogy a szerzetesek kitüntetett szerepet játszottak a karitatív szolgálatban. ${ }^{71}$ Ez a tevékenységük pedig összekapcsolódott a szentségek kiszolgáltatásával, vagyis a megszentelő tevékenységgel vagy a prédikálással, vagyis a tanító küldetéssel. A szerzetesközösségek ma is aktívan jelen vannak a válságterületeken. A szociális problémák enyhítésével részt vesznek a regionális biztonság megteremtésében. Továbbá számos labilis biztonságú országban a szerzetesközösségek oktatási intézményeket tartanak fenn.

Ebben a sorban lehet még megemlíteni a kegyes alapítványokat is, amelyek az egyház liturgikus, nevelő, karitatív tevékenységét támogatják. Jogi szabályozásukat, müködési keretüket a jogalkotó tisztázza. ${ }^{72}$

Sajátos, inkább az eljárásokhoz - tág értelemben vett bírói tevékenységhez - kapcsolódik a boldoggá és szentté avatási eljárást szabályozó joganyag. José Luis Gutiérrez ezeket az eljárásokat a potestas regiminis, a kormányzati hatalom gyakorlás sajátos területének nevezi. ${ }^{73}$ A jelölt életének feltérképezésénél, az „eljárás” alatt figyelmet szentelnek annak a kérdésnek, hogy a jelölt életében hogyan gyakorolta az irgalmas szeretet tetteit. ${ }^{74}$ Az eljárás összetett természetű: az egyház rendelkezik vonatkozó jogszabállyal, az eljárás igazgatási eljárásjogi keretek között folyik, ítélettel zárul. Hasonlóan sajátos a püspökkinevezés előtti eljárás, ahol a jelölt alkalmasságának vizsgálatakor figyelmet kap, hogy hogyan gyakorolja az irgalmas szeretet tetteit. ${ }^{75}$

\section{A szeretet tettei a megszentelő és a tanító küldetésben}

Bár az egyház megszentelő tevékenysége legkézzelfoghatóbban a szentségek és a szentelmények kiszolgáltatása kapcsán jelenik meg, de tág értelmezésében a megszentelés nem csak a liturgikus cselekmények végzését jelenti. Az egyház a szeretet cselekedetei útján „nagyban segíti Krisztus országának a lelkekben való meggyökerezését és megerősödését, és hozzájárulnak a világ üdvösségéhez" (839. k. 1. \$), és ezzel is gyakorolja a megszentelö küldetést.

Az irgalmas Krisztus képét és az egyház a szegények felé való küldetését a teológia legátfogóbban az irgalmasság testi és lelki cselekedeteiben foglalta össze. ${ }^{76}$

70 Domingo i. m. (69. lj.) 291.

71 Erről a kérdésről átfogóan ír: Stephan Haering: Servizio della carità. In Jesús Miñambres (szerk.): Diritto canonico e Servizio della carità. Milano, Giuffrè, 2008. 225-241. 221-241.

72 Ehhez lásd: J. C. Trullols Durán: Naturaleza Jurídica de la „fundaciones pías no autónomas. Pontificia Universitas Sanctae Crucis, Facultas Iuris Canonici, Roma, 2007.

73 Luis José Gutiérrez: Le cause di beatificazione. In Gruppo italiano docenti di diritto canonico (szerk.): I giudizi nella Chiesa. Processi e procedura speciali. Milano, Glossa, 1999. 269-309. 271. Lásd még: Amato Pietro Frutaz: Elementi costitutivi delle cause di beatificazione e di canonizzazione. Rivista di vita spirituale, 30. (1976), 362-375.

74 Gutiérrez i. m. (73. lj.) 307.

75 Thomas Reese: The Selection of Bishops. Woodstock, Woodstock Theological Center, 1984. 5.

76 Az irgalmasság testi cselekedetei: 1 . az éhezőknek ételt adni, 2. a szomjazóknak italt adni, 3. a szegényeket ruházni, 4. az utasoknak szállást adni, 5 . a betegeket és 6 . a börtönben levőket látogatni, 7 . 
A 14 cselekedet közül több közvetve, amíg más cselekedetek közvetlenül jelennek meg az egyház megszentelő vagy tanító küldetésének szabályozásánál.

Tekintve, hogy az egyház eucharisztikus közösség (LG 11; SC 10) nem lehet eltekinteni attól a teológiai vonatkozástól, hogy az eukarisztia alapítása és a krisztusi irgalmas szeretet tette az első pillanattól összekapcsolódott. Amíg a szinoptikus hagyomány az utolsó vacsorán az alapítást emeli ki (Mk 14,22 és Mt 26,26 Lk 22,19), addig János evangéliuma a lábmosás, a szeretet tettét hangsúlyozza (Jn 13, 6). A két hagyomány egymás mellé állítása azt bizonyítja, hogy az alapító az eukarisztia, az egyház legfontosabb liturgikus eseménye mellé helyezte az irgalmasság paradigmáját. A II. Vatikáni Zsinat érdeme, hogy újra hangsúlyozza: az egyház minden tevékenysége, beleértve az irgalmas szeretet tetteit is eucharisztikus vetülettel rendelkezik. ${ }^{77}$ Szimbolikus volt, hogy a szegényeknek juttatott elemózsiát a kezdetekben az eukarisztia ünnepéhez kapcsolódóan osztották ki. Ma sem ritka, hogy a szentmisén összegyủjtött plébániai, egyházmegyei vagy az országos adományokat karitatív célokra ajánlják fel. Emellett - és ez már az egyház tanító küldetéséhez is kapcsolódik - a szentmise sok esetben jelent fórumot, hogy a szolgálattevő az egyház tanításának a fényében a társadalmi igazságtalanságról vagy a szegényekről beszéljen. ${ }^{78}$

A hatályos Kódex általános szentségjogi bevezetőjének utolsó kánonja a szentségkiszolgáltatáshoz kapcsolódó adományok tekintetében hangsúlyozza, hogy a szolgálattevőnek ügyelnie kell, nehogy a szegények a szegénységük miatt nélkülözzék a szentségi segítséget (848. k.). Ez általánosan minden szentség kiszolgáltatása kapcsán alapelv, de a jogalkotó a szentmiseadomány (952. k. 1. \$) és a temetés vonatkozásában ezt külön is nyomatékosítja (1181. k.). Ez utóbbi vonatkozásában a jogalkotó hangsúlyozza, hogy ügyelni kell, nehogy a szegények ne kapják meg a megfelelő temetést. Néhány egyházi temetőben ezért vezették be, hogy a szegényeknek vagy köztemetetteknek ingyen vagy kedvezményes temetkezési lehetőséget biztosítanak. Ebben a tekintetben előfordulhat a helyi önkormányzattal való együttműködés is. Nem ritka, hogy az általános szabályozástól eltérően (1264. k.) a részegyházak és nem a tartomány püspökei szabályozzák a szentségkiszolgáltatás kapcsán az adományokat, és figyelembe véve a szociális kérdéseket, a szegényebb régiók számára alacsonyabb stóladíjat állapítanak meg. ${ }^{79}$ Ez nem is lehet másképp, hiszen a Krisztus-hívőknek joga van ahhoz, hogy az egyház lelki javaiból, különösen az Isten igéjéből és a szentségekből a szent pásztoroktól segítséget kapjanak (213. k.). Az anyagi lehetőségek ennek nem képezhetik akadályát. ${ }^{80}$

a halottakat eltemetni. Az irgalmasság lelki cselekedetei: 1. a bünösöket meginteni, 2. a tudatlanokat tanítani, 3. a kételkedőknek jó tanácsot adni, 4. a szomorúakat vigasztalni, 5. a bántalmakat békével türni, 6. az ellenünk vétkezőknek megbocsátani, 7. az élőkért és holtakért imádkozni.

77 Eugenio Corecco - Libero Gerosa: Il diritto della Chiesa. Milano, Jaca Book, 1995. 105.

78 Paolo Urso: Il ministero della parola divina: predicazione e cathecesi. In Gruppo italiano docenti di diritto canonico (szerk.): La funzione di insegnare della chiesa. Milano, Glossa, 1994. 25-53.

79 Erdő Péter: Az Egyházi Törvénykönyv. Budapest, Szent István Társulat, 1997. 617.

80 Luigi Sabbarese: I fedeli costituiti popolo di Dio. Commento al Codice di Diritto Canonico Libro II, Parte I. Roma, Urbaniana University Press, 2000. 36-37. 
Az egyház megszentelő küldetése amellett, hogy szorosan kapcsolódik a karitászhoz, rámutat, hogy a földi bajok enyhítésén túl az egyház ilyen karitatív igyekezete az ember természetfeletti céljára is rávilágít. ${ }^{81}$

Ami az egyház tanító küldetését és a karitász kapcsolatát illeti, a megszentelő küldetéshez hasonlóan ez is rendkívül szerteágazó terület. Sőt több esetben - mint arra részben már utaltunk - szentségek kiszolgáltatása eleve összekapcsolódik a tanító küldetéssel. A keresztény tanítás átadásának fórumai, mint a prédikáció és a hitoktatás (762. k.) lehetőséget jelentenek az isteni ige szolgáinak, hogy az egyház karitatív szeretetéről szóló tanítását átadják, sőt az egész társadalmat érzékenyítsék. ${ }^{82}$ Érzékelhetően ez utóbbi kapcsán a jelenlegi pápa komoly küldetéstudattal rendelkezik, hiszen a tanítás minden fórumát megragadja, hogy a szegények, a társadalom perifériájára jutottak jogairól és a társadalmi igazságosságról szóljon. A tanító küldetésben, ahogy a megszentelő küldetésben is az egész egyház részt vesz, de mindenki a hierarchiában elfoglalt helyének megfelelően. A hatályos joganyagból látszik, hogy a jogalkotó meglehetősen széles értelmezését veszi a tanító küldetésnek. Számít arra, hogy a különböző fórumok: iskolák (798. k.), akadémiák, konferenciák, gyűlések, sajtó és a többi tömegtájékoztatási eszköz (822-823. kk.) ${ }^{83}$ sajátos lehetőségét adják a keresztény tanítás, közte az irgalmas szeretetre vonatkozó alapelvek átadásának (CD 13; 761. k.). Az isteni ige hirdetőitől a jogalkotó azt várja, hogy ne csak azt tárják fel, amit hinni kell, hanem azt is, amit tenni kell (768. k. 1. \$). „Az egyház szemében a legelső evangelizációs eszköz híveinek őszinte keresztény élete, szoros egységben Istennel, akire teljesen ráhagyatkoznak; másokat szolgáló, áldozatos magatartásuk." ${ }^{84}$ Sajátos fórumát jelentik az irgalmas szeretet és a tanító küldetés kapcsolatának a katolikus (809. k.) és az egyházi egyetemek (815. k.), ahol az egyház társadalmi tanításának mind a szent tudományok, mind a többi tudomány oktatása és kutatása területén meg kell jelennie. Nem ritka, hogy a katolikus felsőoktatási intézmény még szociális munkás szakkal (vagy karral is rendelkezik), amely különleges kapcsolódás a karitatív szeretetről szóló katolikus tanítás és annak tettekre váltása között.

\section{5. Összefoglalás}

A katolikus egyház az alapítótól ráhagyott küldetést a kormányzás, a megszentelés és a tanítás területén gyakorolja. Nincs külön szociális vagy karitatív ág. Azonban a karitász vagy az irgalmas szeretet tettei átjárják a hármas küldetést. Ezért éppen az lenne idegen az egyház természetétől, ha nem az egész „misztikus test” és annak minden tevékenysége vonatkozásában jelenne meg a szegények, a kitaszítottak felé

81 Velasio De Paolis: La chiesa cattolica e il suo ordinamento giuridico. Ius Ecclesiae, 18. (2006), 1. 3-27. 7.; Javier Hervada: Diritto costituzionale canonico. Milano, Giuffrè, 1989. 169.

82 Carlos Errázuriz: La dimensione giuridica del „munus docendi” nella chiesa. Ius Ecclesiae, 1. (1989), 1. 177-193.

83 Agostino Montan: L'educazione cattolica (Cann. 793-821). In Gruppo italiano docenti di diritto canonico (szerk.): La funzione di insegnare della chiesa. Milano, Glossa, 1992. 65-97.

84 Paulus VI: Ex. Ap. Evangelii nuntiandi. Acta Apostolicae Sedis, 68. (1976), 1. 5-76. 31-32. 
való érzékeny szeretet. Hogyan lehetne úgy megszentelésről, tanításról beszélni, ha nem veszi figyelembe az elesetteket, akik különösen is igénylik Isten megerősítő támogatását. Hogyan lehetne kormányzásról beszélni, ha az egyházkormányzatban részt vevő személyek előtt nem a jó pásztor ideája jelenne meg. Az irgalmas szeretet egyfajta kohéziós erő is, amely a három területet: a kormányzást, a megszentelést és a tanítást egyben tartja. A II. Vatikáni Zsinat után a szeretet tetteinek a hármas küldetésben való megjelenítése különösen is hangsúlyossá vált. Ez nemcsak az egyház önazonossága, hanem az államokkal, a nemzetközi szervezetekkel való kapcsolatban is meghatározó szempont. A Szentszék, illetve az egyes nemzetközi és helyi katolikus szervezetek kiveszik a részüket a globális és a regionális válságkezelésben, az emberiség javának előmozdítása érdekében.

A II. Vatikáni Zsinat bizonyos értelemben megelőzte a korát. A Zsinat tanítása, amelyre számos pápai és szentszéki dokumentum épült, prófétai módon készítette fel az egyházat a 20. század második felében megjelenő és napjainkra kulmináló fenyegetettségek, kihívások és válságok kezelésére. Ferenc pápa a Zsinat által körvonalazott irgalmas szeretetre vonatkozó téziseket a globalizált világban a gyakorlatban eminensen alkalmazza. Így válhat a kormányzás, a tanítás és a megszentelés első személyeként a menekültek, a háborúk, a társadalmi igazságtalanság, a korrupció és a szervezett bűnözés áldozatainak segítőjévé a világ előtt.

\section{Irodalomjegyzék}

Franciscus: Adhort. Ap. Evangelium Gaudium. Acta Apostolicae Sedis, 105. (2013), 11. 1019-1138. Benedictus XVI: Litt. Ap. MP. Intima Ecclesiae natura. Acta Apostolicae Sedis, 104. (2012), 11. 9961004.

Benedictus XVI: Enc. Deus Caritas est. Acta Apostolicae Sedis, 98. (2006), 3. 217-279.

Johannes Paulus II: Ex. Ap. Post. Syn., Pastores dabo vobis. Acta Apostolicae Sedis, 84. (1992), 3. 657-804.

Johannes Paulus II: Enc. Centesimus annus. Acta Apostolicae Sedis, 83. (1991), 5. 793-867.

Johannes Paulus II: Ex. Ap. Post. Syn Pastores gregis. Acta Apostolicae Sedis, (2003), 12. 825-924.

Johannes Paulus II: Ex. Ap. Christifideles laici. Acta Apostolicae Sedis, 80. (1988), 12. 893-921.

Johannes Paulus II: Ex. Ap. Post. Syn. Sollicitudo rei socialis. Acta Apostolicae Sedis, 79. (1987), 12. 513-586.

Johannes Paulus II: Const. Ap. Pastor Bonus. Acta Apostolicae Sedis, 80. (1988), 7. 841-934. Johannes Paulus II: Sacrae disciplinae leges. Communicationes, 15. (1983), 1. 8-9.

Johannes Paulus II: Enc., Laborem exercens. Acta Apostolicae Sedis, 73. (1981), 9. 577-647.

Paulus VI: Ex. Ap. Evangelii nuntiandi. Acta Apostolicae Sedis, 68. (1976), 1. 5-76.

Paulus VI: Lit. Ap. Octogesima adveniens. Acta Apostolicae Sedis, 63. (1971), 5. 401-444.

Paulus VI: Enc. Populorum progressio. Acta Apostolicae Sedis, 59. (1967), 3. 257-299.

Johannes XXIII: Enc. Mater et magistra. Acta Apostolicae Sedis, 53. (1961), 5. 401-464.

Pius XI: Enc. Quadragesimo anno. Acta Apostolicae Sedis, 23. (1931), 5. 177-285.

Leo XIII: Enc. Rerum novarum. Acta Apostolicae Sedis, 23. (1931), 5. 641-670.

Igazságosság és Pápai Tanács: Az egyház társadalmi tanításának kompendiuma. Budapest, Szent István Társulat, 2007. 
Az irgalmas szeretet és a karitász jelentősége az egyház hármas - kormányzati...

Humanitarian Law and Religions. Città del Vaticano, Libreria Editrice Vaticana, 2009. Prospettive per un disarmo integrale. Città del Vaticano, Libreria Editrice Vaticana, 2008.

Diritti umani dei detenuti. 2007.

Justice and Peace: An Ever Present Challenge. Città del Vaticano, Libreria Editrice Vaticana, 2004.

Diritto Umanitario e Cappellani Militari. Città del Vaticano, Libreria Editrice Vaticana, 2003.

Words that Matter: The Holy See in Multilateral Diplomacy. New York City, The Path to Peace Foundation, 2003.

Atti del Seminario di Studio del Pontificio Consiglio della Giustizia e della Pace, Roma, Edizioni ART, 2004.

La Chiesa di fronte al razzismo: Per una società più fraterna. Città del Vaticano, Libreria Editrice Vaticana, 1988.

Il commercio internazionale delle armi. Una riflessione etica. Città del Vaticano, Libreria Editrice Vaticana, 1994.

Per una migliore distribuzione della terra. La sfida della riforma agraria. Città del Vaticano, Libreria Editrice Vaticana, 1997.

Refugees: A Challenge to Solidarity. New York, The Center for Migration Studies of New York, 1994. Istentiszteleti Kongregáció: Pontificale Romanum De ordinatione episcopi. Città del Vaticano, Typis Polyglottis Vaticanis, 1990.

Antonini, Orlando: The Diplomatic Activity of the Holy See. Communication, 12. (2015), 2. 5-16.

Appendino, Filippo Natale: La visita pastorale del parroco alle famiglie. Archivo Teologico, 1. (1995), 290-308.

Arangio-Ruiz, Gaetano: On the Nature of the International Personality of the Holy See. Revue Belge de Droit International, 29. (1996), 2. 355-369.

Araujo, R. John: The International Personality and Sovereignty of the Holy See. The Catholic University Law Review, 50. (2001), 2. 292-336.

Barbato, Mariano: A State, a Diplomat, and a Transnational Church. Perspectives, 21. (2013), 2. $27-48$.

Bathon, Matthew: The Atypical International Status of the Holy See. Vanderbilt Journal of Transitional Law, 34. (2001) 3. 597-632.

D’Onorio, Joël-Benoît: Le pape et le gouvernement de l'Eglise. Paris, Fleurus-Tardy, 1992.

Berlingò, Salvatore: Giustizia e carità nell'economia della Chiesa. Contributi per una teoria generale del diritto canonico. Milano, Giappichelli, 1991

Berlingò, Salvatore: Dal mistero al ministero: l'ufficio ecclesiastico. Ius Ecclesiae, 5. (1993), 1. 91-120.

Beyer, Jean: Il diaconato permanente nell'attuale vita ecclesiale. Quaderni di diritto ecclesiale, 10. (1997), 2. 134-142.

Bonicelli, Cesare: Il parroco come pastorale (c. 529. par.). Quaderni di diritto ecclesiale, 6. (1993), 1. 43-49.

Coccopalmerio, Francesco: Il parroco «pastore» della parrocchia. Quaderni di diritto ecclesiale, 6. (1993), 1. 6-22.

Chong, Alan - Troy, Jodok: A Universal Sacred Mission and the Universal Secular Organization: The Holy See and the United Nations. Politics, Religion, and Ideology, 12. (2011), 3. 335-354. DOI: https://doi.org/10.1080/21567689.2011.596417

Condorelli, Orazio: Carità e diritto agli albori della scienza giuridica medievale. In Miñambres, Jesús (szerk.): Diritto canonico e Servizio della carità. Milano, Giuffrè, 2008. 41-92.

Corecco, Eugenio - Gerosa, Libero: Il diritto della Chiesa. Milano, Jaca Book, 1995. 
De La Hera, Alberto: La suprema autoridad de la Iglesia en la codificación canónica latina. Ius Canonicum, 33. (1993), 2. 515-540.

De Paolis, Velasio: La chiesa cattolica e il suo ordinamento giuridico. Ius Ecclesiae, 18. (2006), 1. 3-27.

De Paolis, Velasio: I beni temporali della Chiesa. Canoni preliminari (cann. 1254-1258) e due questioni fundamentali. In Gruppo italiano docenti di diritto canonico (szerk.): I beni temporali della Chiesa. Milano, Glossa, 1997. 9-43.

Domingo, Andres: Le forme di vita consacrata. Commentario teologico - giuridico al Codice di Diritto Canonico. Roma, Ediurcla, 2005.

Duchesne, Louis: The Beginnings of the Temporal Sovereignty of the Popes. New York, Benziger, 1908.

Durán, J. C. Trullols: Naturaleza Jurídica de la „fundaciones pías no autónomas. Pontificia

Universitas Sanctae Crucis, Facultas Iuris Canonici, Roma, 2007.

Erdő Péter: A világiak munkája a plébánián. Távlatok, 12-13. (1993), 3-4. 632-640.

Erdő Péter: Az Egyházi Törvénykönyv. Budapest, Szent István Társulat, 1997.

Errázuriz, Carlos José: La dimensione giuridica del servizio della carità (diakonia) nella chiesa. In Miñambres, Jesús (szerk.): Diritto canonico e Servizio della carità. Milano, Giuffrè, 2008.

Errázuriz Carlos: La dimensione giuridica del „munus docendi” nella chiesa. Ius Ecclesiae, 1. (1989), 1. 177-193.

Faltin, Daniel: De recto usu bonorum ecclesiasticorum ad mentem Concilii Vaticani II. Apollinaris, 40. (1967), 441-442.

Frutaz, Amato Pietro: Elementi costitutivi delle cause di beatificazione e di canonizzazione. Rivista di vita spirituale, 30. (1976), 362-375.

Frivaldszky János: Jó kormányzás és a közjó, politikai és jogfilozófiai szempontból. Budapest, Pázmány Press, 2016.

Ghirlanda, Gianfranco: Potestà di governo. Potestas Regiminis. In Salvador, Corral Carlos - De Paolis, Velasio - Ghirlanda, Gianfranco (szerk.): Nuovo dizionario di diritto canonico. Torino, San Paolo, 1993. 802-803.

Gutiérrez, Luis José: Le cause di beatificazione. In Gruppo italiano docenti di diritto canonico (szerk.): I giudizi nella Chiesa. Processi e procedura speciali. Milano, Glossa, 1999. 269-309.

Graham, Robert: Vatican Diplomacy: a Study of Church and State on the International Plane. New York, Princeton University Press. 1959.

Gratsch, Edward: The Holy See and the United Nations 1945-1995. New York, Vantage Press, 1997. Hanson, Eric: The Catholic Church in World Politics. New York, Princeton University Press, 1987.

Haering, Stephan: Servizio della carità. In Miñambres, Jesús (szerk.): Diritto canonico e Servizio della carità. Milano, Giuffrè, 2008. 225-241.

Harnack, Adolf von: Mission und Ausbreitung des Christentums in den ersten drei Jahrhunderten. Leipzig, 4. Ed. [1902] 1920.

Hebda, A. Bernard: Where Canon Law Connects with Caritas: The Norms of Intima Ecclesiae Natura. A Year of Mercy Examination of Challenges to Compliance in a US Context. The Jurist, 76. (2016), 2. 339-359. DOI: https://doi.org/10.1353/jur.2016.0022

Hervada, Javier: Diritto costituzionale canonico. Milano, Giuffrè, 1989.

Hierold, Alfred: Handbuch des katholischen Kirchenrechts. In Listl, Joseph - Schmitz, Heribert (eds.): Handbuch des katholischen Kirchenrechts. Regensburg, Pustet, 1999.

Jelich, Georg: Kirchliches Ordensverständnis im Wandel. Leipzig, St. Benno, 1983.

Laffitte, Jean: Amore e giustizia nell'enciclica Deus Caritas est: prospettiva teologica. In Miñambres, Jesús (szerk.): Diritto canonico e Servizio della carità. Milano, Giuffrè, 2008. 6-18. 
Az irgalmas szeretet és a karitász jelentősége az egyház hármas - kormányzati...

Levison, Wilhelm: Zur Vorgeschichte der Bezeichnung Servus servorum Dei. Zeitschrift der Savigny-Stiftung für Rechtsgeschichte. Kanonistische Abteilung, 6. (1916), 1. 384-386. DOI: https://doi.org/10.7767/zrgka.1916.6.1.384

Lőrincz Lajos: A közigazgatás alapintézményei. Budapest, HVG-Orac, 2010.

Minelli, Chiara: Diritto canonico e diritto civile nell'impostazione della iniziative di carità. In Miñambres, Jesús (szerk.): Diritto canonico e Servizio della carità. Milano, Giuffrè. 2008. 321-335.

Miñambres, Jesús: Organizzazione gerarchica della Chiesa e servizio della carità. In Miñambres, Jesús ed.: Diritto canonico e servizio della carità. Milano, Giuffrè, 2008. 243-263.

Miñambres, Jesús: Atti Benedetto XVI. Lettera Apostolica MP. Intima Ecclesiae natura sul servizio della carità (11 novembre 2012). Ius Ecclesiae, 25. (2013), 2. 499-532.

Missaglia, Francesco: Contenuto giuridico della pastoralità nella Chiesa del Vaticano II. Diritto e religione, 1. (2006), 1-2. 104-124.

Molano, Eduardo: Commentary on canon 331. In Marzoa, Ángel - Miras, Jorge - RodriguezOcana, Rafael (szerk.): Exegetical Commentary on the Code of Canon Law. Toronto, Wilson \& Lafleur, 2. köt. (2004), 1. 592-593.

Montini, Paolo: Il ministero del parroco (cann. 528-529). In Docenti di diritto canonico, Associazione Canonistica Italiana (szerk.): La parrochia. Milano, Glossa, 2005. 134-135. 125-148.

Montan, Agostino: L'educazione cattolica (Cann. 793-821). In Gruppo italiano docenti di diritto canonico (szerk.): La funzione di insegnare della chiesa. Milano, Glossa, 1992. 65-97.

Morss, R. John: The International Legal Status of the Vatican/Holy See Complex. European Journal of International Law, 26. (2015), 4. 927-946. DOI: https://doi.org/10.1093/ejil/chv062

Navarro, Luis: Le iniziative dei fedeli nel servizio della carità. Fondamento e configurazione giuridica. In Miñambres, Jesús (szerk.): Diritto canonico e Servizio della carità. Milano, Giuffrè, 2008. 193-223.

Padányi József - Földi László: Security Research in the Field of Climate Change. In Nádai László - Padányi József (szerk.): Critical Infrastructure Protection Research: Results of the First Critical Infrastructure Protection Research Project in Hungary. Zürich, Springer, 2016. 79-90. DOI: https://doi.org/10.1007/978-3-319-28091-2_7

Reese, Thomas: The Selection of Bishops. Woodstock, Woodstock Theological Center, 1984.

Resperger István: A válságkezelés kicsit másképp. Nemzetbiztonsági Szemle, 4. (2016), 3. 28-48.

Pavanello, Pierantonio: La determinazione canonica del ministero del diacono permanente Quaderni di diritto ecclesiale, 10. (1997), 2. 143-159.

Pioppi, Carlo: Il servizio della carità nella storia della chiesa: tra creatività e adeguamento ai mutamenti sociali. In Miñambres, Jesús (szerk.): Diritto canonico e Servizio della carità. Milano, Giuffrè, 2008. 105-144.

Del Portillo, Alvaro: Laici e fedeli nella Chiesa. Le basi dei loro statuti giuridici. Milano, Giuffré, 1999.

Sabbarese, Luigi: I fedeli costituiti popolo di Dio. Commento al Codice di Diritto Canonico Libro II, Parte I. Roma, Urbaniana University Press, 2000.

Schmitz, Karl: Ursprung und Geschichte der Devotionsformeln bis zu ihrer Aufnahme in die fränkische Königsurkunde. Stuttgart, Kirchenrechtliche Abhandlungen, von Ulrioh Stutz, 1913.

Schouppe, Jean Pierre: Elementi di diritto patrimoniale canonico. Milano, Giuffrè, 1997. 11.

Semeraro, Marcello: Il ministero episcopale alla luce della ecclesiologia di comunione: visone sintetica della esortazione ap. Pastores gregis. In Cattaneo, Arturo (szerk.): L'esercizio dell'autorità 
nella chiesa. Riflessioni a partire dall'esortazione apostolica. Pastores Gregis. Venezia, Marcianum Press, 2005. 11-23. DOI: https://doi.org/10.1400/120316

Seyersted, Finn: Jurisdiction over Organs and Officials of States, the Holy See and Intergovernmental Organisations. The International and Comparative Law Quarterly, 14. (1965), 1. 31-82. DOI: https://doi.org/10.1093/iclqaj/14.1.31

Ujházi, Lóránd: The Crisis Management of the Apostolic Holy See, or the Achievements of "Soft Power" in Defence of Christian Communities. In Kaló, József - Ujházi, Lóránd (szerk.): Budapest Report 2018 On Christian Persecution. Budapest, Szent István Társulat, Dialóg Campus, 2018. 207-215.

Ujházi Lóránd: Specific Apparatus of Vatican Diplomacy - Charity Organisations. Academic and Applied Research in Military and Public Management Science, 18. (2019), 1. 149-168. DOI: https://doi.org/10.32565/aarms.2019.1.10

Urso, Paolo: Il ministero della parola divina: predicazione e cathecesi. In Gruppo italiano docenti di diritto canonico (szerk.): La funzione di insegnare della chiesa. Milano, Glossa, 1994. 25-53.

Walf, Knut: Commentary on canon 331. In Beal, John - Coriden, James - Green, Thomas (szerk.): The New Commentary on the Code of Canon Law. New York, Paulist Press, 1998. 481.

Nagy Szent Gergely: Patrologia Latina (P.L.) LXXV, 87.

\section{Internetes források}

Fondazione Il Buon Samaritano. Elérhető: www.humandevelopment.va/it/il-dicastero/fondazioni/ il-buon-samaritano.html (A letöltés dátuma: 2020. 02. 19.)

Graziani, Nicola: Come cambierà la Curia con la riforma voluta da Papa Francesco. 2020. Elérhető: www.agi.it/cronaca/news/2020-02-13/riforma-curia-papa-francesco-7036811/ (A letöltés dátuma: 2020. 05. 04.)

Instr. Apostolorum successores. 2004. Elérhető: www.vatican.va/roman_curia/congregations/cbishops/documents/rc_con_cbishops_doc_20040222_apostolorum-successores_en.html (A letöltés dátuma: 2020. 03. 05.)

La Fondazione Sahel contro la desertificazione. Elérhető: www.corunumjubilaeum.va/content/corunumexpo/it/fondazioni/fondazione-giovanni-paolo-ii.html (A letöltés dátuma: 2020. 02 19.)

Special Interviews from Asia: Cardinal Luis Antonio Tagle. Elérhető: www.youtube.com/ watch?v=q2YqAVHgJa8 (A letöltés dátuma: 2020. 03. 05.) 